\title{
АКТУАЛЬНІ ЗАПАСИ ОРГАНІЧНОГО КАРБОНУ В МОРТМАСІ ТА ҐРУНТІ ЛІСОВИХ ЕКОСИСТЕМ СТРИЙСЬКО-СЯНСЬКОЇ ВЕРХОВИНИ НА ТЕРИТОРІЇ ВЕРХНЬОВИСОЦЬКОГО ЛІСНИЦТВА (ДП "БОРИНСЬКИЙ ЛІСГОСП")
}

\begin{abstract}
Досліджено запаси органічного Карбону $\left(C_{\text {ор.. }}\right)$ на території Стрийсько-Сянської Верховини у Верхньовисоцькому ліс-

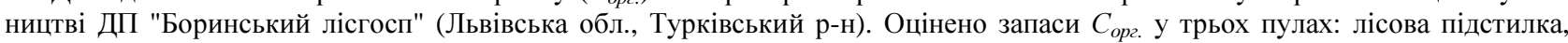
грубі деревні залишки і грунт. Було закладено 22 пробні площі, на яких у 3-разовій повторюваності відібрано зразки підстилки та грунту (з Н і Нр горизонтів). Пробна площа № 11 розташована на території, де було проведено суцільну рубку, під час якої знищено шар лісової підстилки, а після зсув частково або повністю знищив Н і Нр горизонти грунту на площі близько 0,5 га. На кожній пробній площі було закладено ділянку розміром $3 \times 3$ м, на якій проводили облік мертвої деревини (мертва деревина діаметром більше 1 см, пні та мертві стоячі дерева). Вміст органічної речовини у підстилці визначено ме-

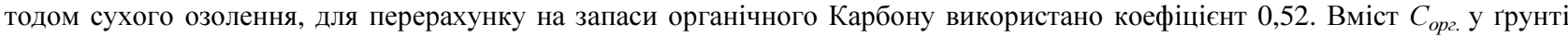
визначено методом Нікітіна, а його запаси - з урахуванням щільності будови грунту в шарі $0,0-0,25$ м. Для визначення запасу органічного Карбону у грубих деревних залишках використано коефіцієнт 0,50 і середнє значення щільності мертвої деревини 345 кг $\mathrm{M}^{-3}$. Встановлено, що запаси органічного Карбону в підстилці змінюються від $3,94^{ \pm 0,24} \mathrm{~T} \cdot \mathrm{ra}^{-1}$ до $9,07^{ \pm 1,72} \mathrm{~T} \cdot \mathrm{ra}^{-1}$,

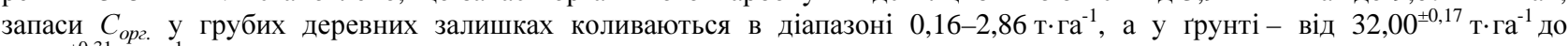
$56,97^{ \pm 0,31} \mathrm{~T} \cdot \mathrm{ra}^{-1}$. Сумарні запаси органічного Карбону в мортмасі та грунті досліджуваних екосистем становлять $34,47-$ $63,77 \mathrm{~T}^{-} \mathrm{ra}^{-1}$. Розраховано, що втрати органічного Карбону у мортмасі і грунті на пробній площі № 11 становлять приблизно $20-27$ т га ${ }^{-1}$.
\end{abstract}

Ключові слова: Українські Карпати; лісова підстилка; мертва деревина; органічна речовина; парникові гази.

Вступ. Проблема глобальної зміни клімату, спричиненої збільшенням концентрації парникових газів в атмосфері, призвела до значної активізації досліджень 3 депонування Карбону лісовими екосистемами. Відповідно до міжнародних кліматичних угод з побудови кадастрів парникових газів особливої актуальності набуло оцінювання бюджету Карбону у лісах на регіональному i національному рівнях (Volodymyrenko et al., 2016). Лiсові екосистеми $є$ найбільшим наземним депо атмосферного Карбону, а більше половини їх чистої первинної продукції надходить у грунт за рахунок трансформації лісового опаду та підстилки. Зміни в запасах Карбону у лісових екосистемах мають істотний вплив на глобальний бюджет Карбону (Grant et al., 2016).

Аналіз літературних джерел. В Україні в різних регіонах проведено низку досліджень з акумуляції органічного Карбону в лісових екосистемах. Проте тільки у роботі В. Пастернака (2011) оцінено запаси органічного Карбону у фітомасі, підстилці і стовбуровому фітодетриті (Pasternak, 2011). У роботі П. Лакиди оцінено фіто- масу лісів України і запропоновано формули для оцінки запасів органічного Карбону в інших пулах вуглецю (Lakyda, 2002). У публікації I. Шпаківсьої і О. Марискевич наведено оцінку запасів органічного Карбону в лісових екосистемах Сколівських Бескид за даними лісової таксації з використанням відповідних коефіцієнтів (Shpakivska \& Maryskevych, 2009). Проте, як зазначають інші дослідники, достовірніші результати можна отримати комбінуючи польові і розрахункові методи (Alekseyev \& Berdsi, 1994; Grant et al., 2016). Зокрема, В. Рожак у своїй роботі описав особливості формування циклу органічного Карбону у лісових екосистемах Стрийсько-Сянської Верховини (Rozhak, 2014). I. Пижик і I. Шпаківська провели оцінку запасів органічного Карбону у лісовій підстилці і грубих деревних залишках на території РЛП "Надсянський" (пробні площі заклали на території Яблунського лісництва ДП "Боринський лісгосп") (v). Натепер залишається актуальним проведення детальних досліджень запасів органічного Карбону в мортмасі і лісових екосистем та верхніх горизон-

\section{Інформація про авторів:}

Пижик Iгор Степанович, пров. інженер, відділ екосистемологіï. Email: igorpyzhyk@gmail.com; https://orcid.org/0000-0001-6594-0499

Шпаківська Ірина Миронівна, канд. біол. наук, ст. наук. співробітник, відділ екосистемологіï. Email: ishpakivska@ukr.net; https://orcid.org/0000-0002-5152-6083

Цитування за ДСтУ: Пижик І. С., Шпаківська І. М. Актуальні запаси органічного карбону в мортмасі та ґрунті лісових екосистем Стрийсько-Сянської верховини на території Верхньовисоцького лісництва (ДП "Боринський лісгосп"). Науковий вісник НЛТУ України. 2019, т. 29, № 9. С. 15-21.

Citation APA: Pyzhyk, I. S., \& Shpakivska, I. M. (2019). Actual stocks of the organic carbon in mortmas and soils of forestry ecosystems of the Stryi-Sianskaya Verkhovyna in the territory of the Vernovysotske forestry (Borin forestry enterprise). Scientific Bulletin of UNFU, 29(9), 15-21. https://doi.org/10.36930/40290902 
тах грунту на регіональному рівні, зокрема в експлуатаційних лісах.

Об'єктом дослідження є органічний Карбон у компонентах лісових екосистем Верховини.

Предмет дослідження - методи і засоби встановлення значення величини актуальних запасів $\left(\mathrm{T}^{\cdot} \mathrm{ra}^{-1}\right)$ органічного Карбону.

Мета дослідження - оцінити актуальні запаси органічного Карбону у мортмасі та грунті лісових екосистем Стрийсько-Сянської Верховини.

Для досягнення мети роботи поставлено такі основні завдання:

- аналіз лісівничо-таксаційних характеристик деревостанів регіону та інших літературних джерел, пов'язаних з темою територією дослідження;

- підбір пробних площ на підставі лісотаксаційних матеріалів i консультацій 3 працівниками лісогосподарського підприємства;

- відбір зразків грунту і лісової підстилки і оцінювання запасів грубих деревних залишків;

- проведення лабораторних аналізів;

- проведення порівняння отриманих даних з даними попередніх досліджень досліджуваної території.

Наукова новизна роботи полягає в тому, що вперше проведено комплексну регіональну оцінку депонування органічного вуглецю у компонентах лісових екосистемам Українських Карпат, його просторового розподілу на прикладі Стрийсько-Сянської Верховини, виявлено вплив на нагромадження вуглецю абіотичних та біотичних факторів, оцінено зменшення кількості його депонування внаслідок антропогенного вилучення деревини за різних способів лісокористування.

Територія дослідження. Дослідні полігони розташовані на території Стри́йсько-Ся́нської Верхови́ни фізико-географічного району Українських Карпат в межах Турківського і Сколівського р-нів Львівської обл. у верхів'ях річок Опору, Стрию та Сяну (рис. 1). За даними дистанційного зондування Землі на підставі дешифрування супутникових знімків Landsat встановлено, що загальна площа Стрийсько-Сянської Верховини становить 130254 га, а площа вкрита лісом 60191 га (46,2 \%) 3 переважанням хвойних лісів, які займають 29,3\% (Tsunyak et al., 2013). Дослідні площі було приурочено до території Верхньовисоцького лісництва ДП "Боринське ЛГ". Загальна площа лісництва 2528 га, вкриті лісовою рослинністю землі - 2189,5 га, лісові культури становлять $15 \%$ від вкритої лісом площі (Forestry, 2019). Верхньовисоцьке лісництво є експлуатаційним і на його території проводять різні лісогосподарські заходи, заготівлю деревини різними видами рубань та створення лісових культур, зокрема введення до складу деревостану модрини європейської.

Матеріали і методи дослідження. Для оцінки актуального запасу органічного Карбону мортмаси в експлуатаційних лісах Стрийсько-Сянської Верховини на території Верхньовисоцького лісництва провели дослідження його запасів та просторового розподілу з урахуванням лісотаксаційних характеристик (склад, повнота та вік деревостану) та абіотичних умов території (висота н.р.м., експозиція та крутизна схилу).

На території лісництва заклали 22 дослідні ділянки (табл. 1 і рис. 1), на яких в 3-разовій повторюваності відбирали проби підстилки методом Скородумова за допомогою рамки зі сторонами $25 \mathrm{~cm}$ (Skorodumov,
1939). Загалом було відібрано 66 зразків лісової підстилки.

На кожній пробній площі відбирали у 3-разовій повторюваності зразки грунту з Н та Нр горизонтів, загалом було відібрано 126 зразків грунту. Визначення мінеральної частини у підстилці здійснено методом сухого озолення у муфельній печі за температури 450$500{ }^{\circ} \mathrm{C}$ впродовж 5-8 год (Vazhenyna, 1974).

У межах дослідних ділянок закладено пробні площі розміром $3 \times 3$ м та проведено облік лежачого і стоячого стовбурового фітодетриту (ламань) і пнів, після чого зроблено перерахунок на вміст $C_{\text {орг. }}$. До грубих деревних залишків зараховували гілки діаметром більше 1 см, сухі стоячі дерева заввишки більше 1,3 м та пні, висота яких менше 1,3 м (Bilous, 2014). Для розрахунків

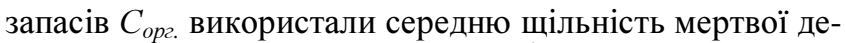
ревини для цієї території 345 кг· $\mathrm{M}^{-3}$ (Rozhak, 2014). Для перерахунку вмісту органічного Карбону використовували коефіцієнт 0,52 для лісової підстилки і 0,50 для грубих деревних залишків (Chestnykh, Lyzhin \& Koksharova, 2007).

Використовуючи програму Google Earth Pro, карту грунтів Турківського р-ну і координати, отримані під час польових досліджень, визначили типи грунтів, до яких приурочені дослідні ділянки. Для розрахунку запасів органічного Карбону використано дані щільності будови грунту (Golubets, 2007).

Результати дослідження та їх обговорення. Актуальні запаси органічного Карбону визначали у компонентах мортмаси: підстилці, грубих деревних залишках та органічній речовині грунтів.

Процес накопичення та розкладання мортмаси підстилки і грубих деревних залишків залежить від породного складу, віку, формули деревостану, зімкнутості та живого надгрунтового покриву лісової екосистеми, а кількість органічного Карбону в грунті є функцією процесів гуміфікації та мінералізації органічних решток, які потрапляють на поверхню грунту (Pyzhyk \& Shpakivs'ka, 2018).

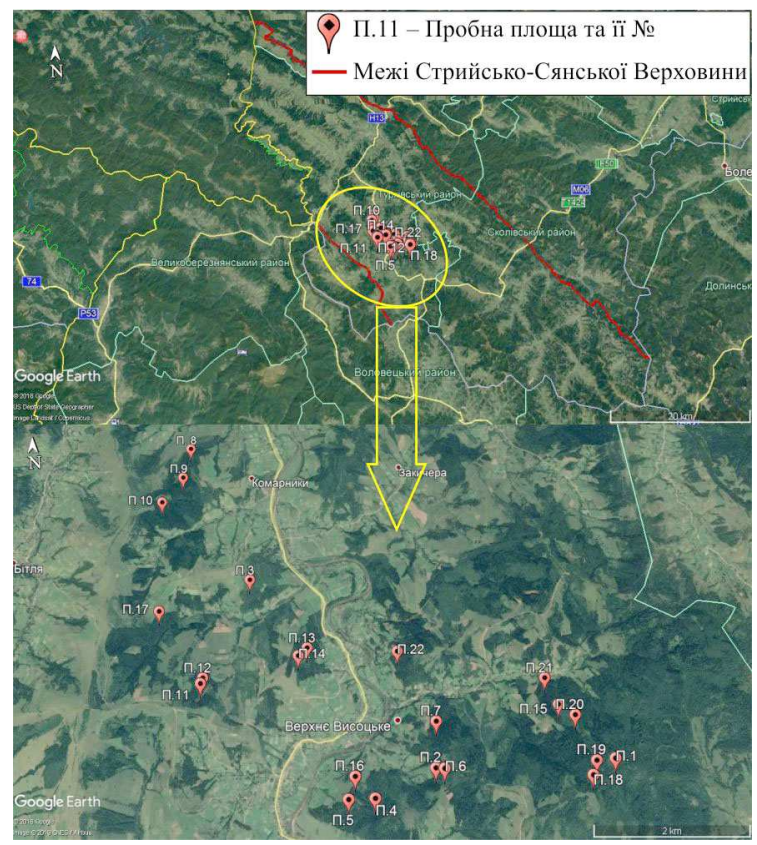

Рис. 1. Локалізація дослідних ділянок території СтрийськоСянської Верховини та Верхньовисоцького лісництва 
Табл. 1. Коротка характеристика та локалізація дослідних ділянок на території

Верхньовисцького лісництва Боринського ДЛГП

\begin{tabular}{|c|c|c|c|c|c|}
\hline $\begin{array}{l}№ \\
\Pi / \Pi\end{array}$ & $\begin{array}{c}\text { Квартал / } \\
\text { виділ }\end{array}$ & $\begin{array}{c}\text { Формула деревостану / } \\
\text { повнота }\end{array}$ & $\begin{array}{c}\text { Вік деревостану, } \\
\text { років }\end{array}$ & Координати & $\begin{array}{c}\text { Експозиція, крутизна схилу, } \\
\text { висота н.р.м. }\end{array}$ \\
\hline 1 & $24 / 7$ & 10Бкл+Яле/0,7 & 65 & $\begin{array}{l}\mathrm{N} 48^{\circ} 56^{\prime} 39,0^{\prime \prime} \\
\mathrm{E} 23^{\circ} 06^{\prime} 32,0^{\prime \prime}\end{array}$ & східна, $12-18^{\circ}, 848$ м \\
\hline 2 & $19 / 41$ & 9Яцб1Яле/07 & 75 & $\begin{array}{l}\mathrm{N} 48^{\circ} 56^{\prime} 39,0^{\prime \prime} \\
\mathrm{E} 23^{\circ} 04^{\prime} 31,0^{\prime \prime}\end{array}$ & північно-західна, 7-10, 713 м \\
\hline 3 & $9 / 31$ & 8Сз2Яле/0,7 & 44 & $\begin{array}{l}\mathrm{N} 48^{\circ} 58^{\prime} 12,0^{\prime \prime} \\
\mathrm{E} 23^{\circ} 02^{\prime} 36,6^{\prime \prime}\end{array}$ & південна, $10-15^{\circ}, 747$ м \\
\hline 4 & $22 / 1$ & 10Яле/0,5 & 50 & $\begin{array}{l}\mathrm{N} 48^{\circ} 56^{\prime} 28,0^{\prime \prime} \\
\text { E } 23^{\circ} 03^{\prime} 56,6^{\prime \prime}\end{array}$ & південна, $7-10^{\circ}, 743$ м \\
\hline 5 & $22 / 18$ & 10Яле/0,5 & 67 & $\begin{array}{l}\text { N } 48^{\circ} 56^{\prime} 39,4^{\prime \prime} \\
\text { E } 23^{\circ} 04^{\prime} 38,0^{\prime \prime}\end{array}$ & південна, 5-10, 669 м \\
\hline 6 & $18 / 51$ & 8Яле2Яцб/0,9 & 21 & $\begin{array}{l}\text { N } 48^{\circ} 56^{\prime} 38,9^{\prime \prime} \\
\text { E } 23^{\circ} 04^{\prime} 43,6^{\prime \prime}\end{array}$ & південна, 5-7º, 750 м \\
\hline 7 & $18 / 17$ & 8Яцб2Яле+Сз/0,7 & 90 & $\begin{array}{l}\mathrm{N} 48^{\circ} 56^{\prime} 59,5^{\prime \prime} \\
\mathrm{E} 23^{\circ} 04^{\prime} 40,6^{\prime \prime}\end{array}$ & північна, 7-10, 737 м \\
\hline 8 & $4 / 3$ & 10Яле/05 & 43 & $\begin{array}{l}\mathrm{N} 48^{\circ} 59^{\prime} 32,0^{\prime \prime} \\
\text { E } 23^{\circ} 01^{\prime} 42,4^{\prime \prime}\end{array}$ & північно-східна, 5-10, 740 м \\
\hline 9 & $4 / 19$ & 8Яле2Яцб/0,6 & 75 & $\begin{array}{l}\mathrm{N} 48^{\circ} 59^{\prime} 11,9^{\prime \prime} \\
\mathrm{E} 23^{\circ} 01^{\prime} 39,7^{\prime \prime}\end{array}$ & північно-західна, 4-7, 810 м \\
\hline 10 & $4 / 28$ & 10Яцб/0,8 & 62 & $\begin{array}{l}\text { N } 48^{\circ} 58^{\prime} 54,0^{\prime \prime} \\
\text { E } 23^{\circ} 01^{\prime} 29,5^{\prime \prime}\end{array}$ & південна, 15-20, 749 м \\
\hline 11 & $12 / 30$ & зруб 2016 року & - & $\begin{array}{l}\mathrm{N} 48^{\circ} 57^{\prime} 21,1^{\prime \prime} \\
\mathrm{E} 23^{\circ} 02^{\prime} 03,9^{\prime \prime}\end{array}$ & північно-західна, 10-15, 740 м \\
\hline 12 & $12 / 30$ & 10Яле+Яцб/0,7 & 75 & $\begin{array}{l}\mathrm{N} 48^{\circ} 57^{\prime} 23,9^{\prime \prime} \\
\mathrm{E} 23^{\circ} 02^{\prime} 05,0^{\prime \prime}\end{array}$ & північно-західна, 10-15, 717 м \\
\hline 13 & $13 / 14$ & 8Яле2Бкл/0,5 & 25 & $\begin{array}{l}\text { N } 48^{\circ} 57^{\prime} 36,4^{\prime \prime} \\
\mathrm{E} 23^{\circ} 03^{\prime} 15,5^{\prime \prime}\end{array}$ & східна, 7-12, 736 м \\
\hline 14 & $13 / 50$ & 10Яле/0,8 & 47 & $\begin{array}{l}\text { N } 48^{\circ} 57^{\prime} 32,4^{\prime \prime} \\
\text { E } 23^{\circ} 03^{\prime} 09,6^{\prime \prime}\end{array}$ & східна, $8-15^{\circ}, 761$ м \\
\hline 15 & $20 / 16$ & 10Яле/0,7 & 35 & $\begin{array}{l}\text { N } 48^{\circ} 57^{\prime} 07,3^{\prime \prime} \\
\text { E } 23^{\circ} 06^{\prime} 06,4^{\prime \prime}\end{array}$ & західна, 3-5, 779 м \\
\hline 16 & $18 / 41$ & 10Яле/0,7 & 30 & $\begin{array}{l}\mathrm{N} 48^{\circ} 56^{\prime} 37,5^{\prime \prime} \\
\mathrm{E} 23^{\circ} 03^{\prime} 46,3^{\prime \prime}\end{array}$ & північно-східна, $0-2^{\circ}, 714$ м \\
\hline 17 & $9 / 4$ & 10Яцб/0,6 & 87 & $\begin{array}{l}\mathrm{N} 48^{\circ} 57^{\prime} 57,8^{\prime \prime} \\
\text { E } 23^{\circ} 01^{\prime} 30,6^{\prime \prime}\end{array}$ & східна, $8-12^{\circ}, 733$ м \\
\hline 18 & $19 / 41$ & 6Яцб2Яле2Бкл/0,6 & 55 & $\begin{array}{l}\mathrm{N} 48^{\circ} 56^{\prime} 33,0^{\prime \prime} \\
\mathrm{E} 23^{\circ} 06^{\prime} 16,6^{\prime \prime}\end{array}$ & південно-східна, 0-2, 816 м \\
\hline 19 & $19 / 42$ & 10яле/0,7 & 35 & $\begin{array}{l}\text { N } 48^{\circ} 56^{\prime} 38,9^{\prime \prime} \\
\text { E } 23^{\circ} 16^{\prime} 20,2^{\prime \prime}\end{array}$ & західна, 5-10, 831 м \\
\hline 20 & $19 / 17$ & 8Яцб2Яле/0,5 & 82 & $\begin{array}{l}\mathrm{N} 48^{\circ} 56^{\prime} 59,1^{\prime \prime} \\
\mathrm{E} 23^{\circ} 05^{\prime} 11,9^{\prime \prime}\end{array}$ & південно-західна, 0-2, 799 м \\
\hline 21 & $21 / 3$ & 5Яцб5Яле/05 & 50 & $\begin{array}{l}\text { N } 48^{\circ} 57^{\prime} 17,4^{\prime \prime} \\
\text { E } 23^{\circ} 05^{\prime} 56,7^{\prime \prime}\end{array}$ & північно-східна, $10-15^{\circ}, 713$ м \\
\hline 22 & $14 / 18$ & 10Яле/0,5 & 58 & $\begin{array}{l}\text { N } 48^{\circ} 57^{\prime} 33,2^{\prime \prime} \\
\text { E } 23^{\circ} 04^{\prime} 17,7^{\prime \prime}\end{array}$ & західна, 7-10, 712 м \\
\hline
\end{tabular}

Мортмаса і грунт, завдяки своїм взаємозв'язкам i безпосередньому контакту між своїми компонентами, відіграють важливу роль у системі кругообігу органічного Карбону у лісових екосистемах. Вони водночас виступають резервуарами його довготривалого зберігання в екосистемі, 3 якого Карбон у доступній формі надходить різним живим організмам і депонується в атмосферy (Alekseyev \& Berdsi, 1994; Banaś et al., 2014; Chestnykh, Lyzhin \& Koksharova, 2007; Golubets, 2007; Grant et al., 2016; Matsala \& Bilous, 2017; Pyzhyk \& Shpakivs'ka, 2018; Rozhak, 2014; Shpakivska \& Maryskevych, 2009).

Встановлено, що запас підстилки у Верхньовисоцькому лісництві змінюється від $8,17 \mathrm{~T}^{\cdot} \mathrm{ra}^{-1}$ до $18,59 \mathrm{~T}^{\cdot} \mathrm{ra}^{-1}$ (ПП № 19 і 12 відповідно), а органічного Карбону - від $3,94^{ \pm 0,24} \mathrm{~T}^{\cdot} \mathrm{ra}^{-1}$ до $9,07^{ \pm 1,72} \mathrm{~T}^{\cdot} \mathrm{ra}^{-1}$. Запаси грубих деревних залишків змінюються від $0,32 \mathrm{~T}^{\cdot} \mathrm{ra}^{-1}$ до $5,73 \mathrm{~T}^{\cdot} \mathrm{ra}^{-1}$, а

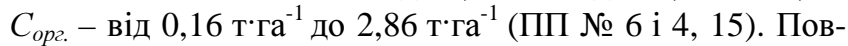
ністю відсутня лісова підстилка на пробній площі № 11, що є наслідком проведення суцільної рубки головного користування на території близько 0,5 га в попередні роки.

У молодняках (вік деревостану 0-40 років) запас підстилки і органічного Карбону змінюється у діапазоні $8,17 \mathrm{\tau}^{*} \mathrm{ra}^{-1}$ до $15,90 \mathrm{~T}^{\cdot} \mathrm{ra}^{-1}$ для підстилки і від $3,94^{ \pm 024} \mathrm{~T}^{*} \mathrm{ra}^{-1}$

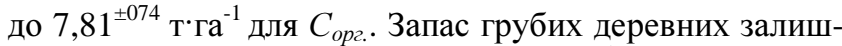
ків коливається у межах $0,32-5,18 \mathrm{~T}^{*} \mathrm{ra}^{-1}$, а органічного Карбону - від 0,16 т•га ${ }^{-1}$ до 2,59 т*га ${ }^{-1}$

У середньовікових деревостанах запаси лісової підстилки та органічного Карбону коливаються у межах 9,42-15,80 т`га ${ }^{-1}$ для лісової підстилки і від 4,36 ${ }^{ \pm 064} \mathrm{~T}^{*} \mathrm{ra}^{-1}$ до $7,67^{ \pm 084} \mathrm{~T}^{\cdot} \mathrm{ra}^{-1}$ для $C_{\text {орг. }}$, а запас грубих деревних залишків i органічного Карбону - від $0,62 \mathrm{~T}^{*} \mathrm{ra}^{-1}$ до5,18 т•га ${ }^{-1}$ і від 0,31 т•га ${ }^{-1}$ до 2,59 т'га ${ }^{-1}$ відповідно.

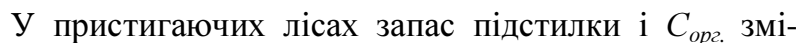
нюється в межах - від 8,48 т*га ${ }^{-1}$ до $18,59 \mathrm{~T}^{\cdot} \mathrm{ra}^{-1} \mathrm{i}$

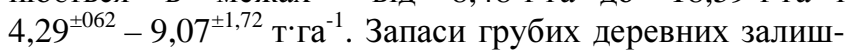


ків перебувають у діапазоні 0,35-4,24 т га ${ }^{-1}$, а органічного Карбону - 0,17-2,07 т•га ${ }^{-1}$.

Стиглі та перестійні ліси характеризуються запасами підстилки від 10,61 до 16,25 т•га ${ }^{-1}$, а запаси органічного Карбону коливаються в межах - 5,05 $5^{ \pm 0,27}$ $7,75^{ \pm 068} \mathrm{~T}^{\cdot} \mathrm{ra}^{-1}$. Запас грубих деревних залишків коливається у межах від 3,00 до 5,73 тга ${ }^{-1}$, а $C_{\text {ор. }}-1,22-$ 2,86 т*га ${ }^{-1}$ відповідно.
Середнє значення запасів органічного Карбону у підстилці на території Яблунського лісництва, яке було розраховано на підставі даних лісової таксації, становило 4 т.га ${ }^{-1}$ (Shpakivska \& Maryskevych, 2009). Запаси органічного Карбону у лісових екосистемах СтрийськоСянської Верховини (дослідження також проводили на території ДП Боринське ЛГ) в межах 4,67-9,26 т. га ${ }^{-1}$ (Rozhak, 2014).

Табл. 2. Запаси органічного Карбону у мортмасі лісових екосистем Верхньовисоцького лісництва

\begin{tabular}{|c|c|c|c|c|c|c|}
\hline $\begin{array}{c}\text { № } \\
\text { п/П } \\
\end{array}$ & $\begin{array}{c}\text { Формула } \\
\text { деревостану }\end{array}$ & $\begin{array}{c}\text { Вік } \\
\text { деревостану } \\
\end{array}$ & $\begin{array}{c}\text { Запаси підстилки, } \\
{\text { т } \text { ra }^{-1}} \\
\end{array}$ & $\begin{array}{c}\text { Запаси дебрису, } \\
\text { т.ra }^{-1} \\
\end{array}$ & $\begin{array}{c}\text { Запаси } C_{\text {орг. }} \text { У під- } \\
\text { стилці, т. }{ }^{-1}\end{array}$ & $\begin{array}{l}\text { Запаси } C_{\text {op.. }} \mathrm{y}^{-1} \\
\text { дебрисі, т.га }\end{array}$ \\
\hline \multicolumn{7}{|c|}{ Молоді ліси, вік 0-40 років } \\
\hline 6 & 8Яле2Яцб & 21 & $8,89^{ \pm 0,41}$ & 0,32 & $4,26^{ \pm 0,24}$ & 0,16 \\
\hline 13 & 8Яле2Бкл & 25 & $12,74^{ \pm 0,30}$ & 0,69 & $6,17^{ \pm 0,23}$ & 0,35 \\
\hline 15 & 10Яле & 35 & $9,81^{ \pm 1,17}$ & 5,18 & $4,68^{ \pm 0,65}$ & 2,59 \\
\hline 16 & 10Яле & 30 & $15,90^{ \pm 0,79}$ & 4,49 & $7,81^{ \pm 0,47}$ & 2,24 \\
\hline 19 & 10Яле & 35 & $8,17^{ \pm 0,30}$ & 1,41 & $3,94^{ \pm 0,24}$ & 0,71 \\
\hline \multicolumn{7}{|c|}{ Середньовікові ліси, вік 40-60 років } \\
\hline 3 & 8Сз2Яле & 44 & $14,33^{ \pm 2,10}$ & 1,73 & $6,95^{ \pm 0,98}$ & 0,86 \\
\hline 4 & 10Яле & 50 & $9,42^{ \pm 0,90}$ & 5,18 & $4,36^{ \pm 0,46}$ & 2,59 \\
\hline 8 & 10Яле & 43 & $15,80^{ \pm 1,64}$ & 0,62 & $7,67^{ \pm 0,84}$ & 0,31 \\
\hline 14 & 10Яле & 47 & $10,22^{ \pm 0,50}$ & 0,66 & $4,96^{ \pm 0,27}$ & 0,33 \\
\hline \multicolumn{7}{|c|}{ Пристигаючі ліси, вік 60-80 років } \\
\hline 1 & 10Бкл+Яле & 65 & $13,07^{ \pm 0,92}$ & 1,45 & $6,27^{ \pm 0,60}$ & 0,72 \\
\hline 2 & 9Яцб1Яле & 75 & $11,18^{ \pm 1,66}$ & 3,35 & $5,32^{ \pm 0,72}$ & 1,67 \\
\hline 5 & 10Яле & 67 & $17,29^{ \pm 1,05}$ & 3,73 & $8,26^{ \pm 1,26}$ & 1,86 \\
\hline 9 & 8Яле2Яцб & 75 & $13,40^{ \pm 2,32}$ & 2,32 & $5,43^{ \pm 1,22}$ & 1,16 \\
\hline 10 & 10Яцб & 62 & $16,25^{ \pm 3,57}$ & 0,35 & $7,67^{ \pm 1,74}$ & 0,17 \\
\hline 12 & 10Яле+Яцб & 75 & $18,59^{ \pm 3,16}$ & 2,5 & $9,07^{ \pm 1,72}$ & 1,25 \\
\hline 18 & $\begin{array}{l}\text { 6Яцб2Яле } \\
\text { 2Бкл }\end{array}$ & 55 & $13,09^{ \pm 0,41}$ & 3,21 & $6,22^{ \pm 0,38}$ & 1,60 \\
\hline 21 & 5Яцб5Яле & 50 & $12,8^{ \pm 0,61}$ & 4,14 & $6,90^{ \pm 0,44}$ & 2,07 \\
\hline 22 & 10Яле & 58 & $8,84^{ \pm 1,06}$ & 1,38 & $4,29^{ \pm 0,62}$ & 0,67 \\
\hline \multicolumn{7}{|c|}{ Стиглі і перестійні ліси, вік понад 80 років } \\
\hline 7 & $\begin{array}{c}8 \text { Яцб } \\
2 \text { Яле+Сз } \\
\end{array}$ & 90 & $15,08^{ \pm 1,41}$ & 5,73 & $7,09^{ \pm 0,82}$ & 2,86 \\
\hline 17 & 10Яцб & 87 & $16,25^{ \pm 0,99}$ & 2,45 & $7,75^{ \pm 0,68}$ & 1,22 \\
\hline 20 & 8Яцб2Яле & 82 & $10,61^{ \pm 0,38}$ & 3,00 & $5,05^{ \pm 0,27}$ & 1,50 \\
\hline \multicolumn{7}{|c|}{ Зруб. Грудень 2016.} \\
\hline 11 & - & - & 0 & 4,93 & 0 & 2,47 \\
\hline
\end{tabular}

За результатами наших польових досліджень встановлено, що запаси $\mathrm{C}_{\text {орг. }}$ у Яблунському лісництві мають більшу просторову варіабельність - 2,05-11,04 т•га ${ }^{1}$ (Pyzhyk \& Shpakivs'ka, 2018). Раніше було встановле-

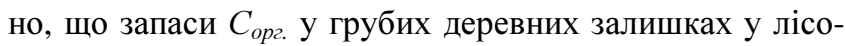
вих екосистемах Стрийсько-Сянської Верховини змінюються від 3,83 т. га ${ }^{-1}$ до 23,50 т. га ${ }^{-1}$ у ДП "Боринське ЛГ" (Rozhak, 2014). Середні запаси органічного Карбону у стовбуровому фітодетриті, розраховані за даними лісової таксації, у Яблунському лісництві становили 0,9 т.га ${ }^{-1}$ (Shpakivska \& Maryskevych, 2009). Під час польових досліджень, які ми здійснили у 2016 р., з'ясо-

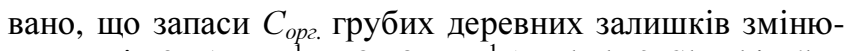
ються від 0,71 т·га ${ }^{-1}$ до 8,63 т· га ${ }^{-1}$ (Pyzhyk \& Shpakivs'ka, 2018).

Основними типами грунтів на території дослідження $\epsilon$ бурі лісові та дерново-буроземні грунти. Відповідно до детальної карти грунтового покриву Турківського рну, дослідні ділянки приурочені до різних підтипів бурих лісових грунтів (з різним рівнем щебенюватості, змитості та потужності грунтового профілю з проявами різних елементарних грунтотвірних процесів: опідзолення та оглеєння) і дерново-буроземних грунтів (Golubets, 2007).
Встановлено, що запаси органічного Карбону у шарі грунту 0,0-0,25 м коливаються від $32,00^{ \pm 1,68} \mathrm{~T} \cdot \mathrm{ra}^{-1}$ до

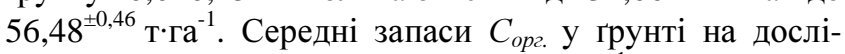
джуваній території становлять 46,56 т.га ${ }^{-1}$.

Загалом отримані дані збігаються з результатами інших дослідників. Так, було встановлено, що у лісових екосистемах ДП Боринське ЛГ запаси $C_{\text {орг. }}$ у грунті змінюються від 35,23 до 43,37 т·га ${ }^{-1}$ для глибини 0,0-0,20 м

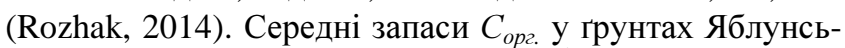
кого лісництва становили 62,00 т·га ${ }^{-1}$ для глибини 0,00,50 см (Shpakivska \& Maryskevych, 2009).

Суцільні рубки можуть зумовлювати значний вплив на запаси органічного Карбону не лише в лісовій підстилці, але і в грунтовому профілі. Наприклад, на пробній площі № 11 Верхньовисоцького лісництва дослідні ділянки також заклали на бурих лісових глибоких грунтах, проте запаси органічного Карбону тут значно відрізняються від інших пробних площ, закладених на такому самому типі грунту (табл. 3). Така значна різниця пов'язана 3 тим, що на ПП № 11 після суцільної рубки було майже на всій площі зруйновано Н і частково Нp горизонти внаслідок робіт лісозаготівельної техніки і наступного зсуву, який стався після знищення рослинного покриву. 
Табл. 3. Вміст і запаси органічного Карбону у шарі грунту 0-0,25 м у лісових екосистемах Верхньовисоцького лісництва

\begin{tabular}{|c|c|c|c|c|c|c|c|c|}
\hline $\begin{array}{l}\text { № } \\
\Pi / \Pi\end{array}$ & $\begin{array}{c}\text { Формула } \\
\text { деревостану }\end{array}$ & $\begin{array}{c}\text { Вік дере- } \\
\text { востану }\end{array}$ & $\begin{array}{c}\text { Тип грунту: шифр грунту на карті } \\
\text { / назва грунту }\end{array}$ & $\begin{array}{l}\text { Грунтові } \\
\text { горизонти }\end{array}$ & $\begin{array}{c}\text { Глибина } \\
\text { відбору } \\
\text { проби. см }\end{array}$ & $\begin{array}{c}\text { Вміст } C_{\text {opz. }} \\
\%\end{array}$ & $\begin{array}{l}\text { Вміст гу- } \\
\text { мусу \% }\end{array}$ & $\begin{array}{l}\text { Запаси } C_{o p 2,} \\
\text { т.га }{ }^{-1} *\end{array}$ \\
\hline \multicolumn{9}{|c|}{ Молоді ліси, вік 0-40 років } \\
\hline \multirow{2}{*}{6} & \multirow{2}{*}{ 8Яле2Яцб } & \multirow{2}{*}{21} & \multirow{2}{*}{ Бурі лісові неглибокі щебенюваті } & $\mathrm{H}$ & $0-1,0$ & 3,00 & 5,16 & \multirow{2}{*}{$34,33^{ \pm 1,68}$} \\
\hline & & & & $\mathrm{Hp}$ & $1,0-25,5$ & 1,13 & 1,95 & \\
\hline \multirow{2}{*}{13} & \multirow{2}{*}{ 8Яле2Бкл } & \multirow{2}{*}{25} & \multirow{2}{*}{ Бурі лісові глибокі } & $\mathrm{H}$ & $0-2,0$ & 3,63 & 6,26 & \multirow{2}{*}{$49,33^{ \pm 1,84}$} \\
\hline & & & & $\mathrm{Hp}$ & $2,0-28,0$ & 1,51 & 2,61 & \\
\hline \multirow{2}{*}{15} & \multirow{2}{*}{ 10Яле } & \multirow{2}{*}{35} & \multirow{2}{*}{$\begin{array}{c}\text { Бурі лісові середньоглибокі сла- } \\
\text { бозмиті щебенюваті }\end{array}$} & $\mathrm{H}$ & $0-6,0$ & 3,41 & 5,87 & \multirow{2}{*}{$51,62^{ \pm 2,21}$} \\
\hline & & & & $\mathrm{Hp}$ & $6,0-40,0$ & 1,32 & 2,28 & \\
\hline \multirow{2}{*}{16} & \multirow{2}{*}{ 10Яле } & \multirow{2}{*}{30} & \multirow{2}{*}{$\begin{array}{l}\text { Бурі лісові неглибокі слабозмиті } \\
\text { щебенюваті }\end{array}$} & $\mathrm{H}$ & $0-2,0$ & 2,70 & 4,65 & \\
\hline & & & & $\mathrm{Hp}$ & $2,0-24,0$ & 1,15 & 1,98 & $38,43^{-\infty, 00}$ \\
\hline 10 & $109_{\text {пе }}$ & 35 & Бурі лісові середньоглибокі сла- & $\mathrm{Hp}$ & $0-3,0$ & 3,42 & 5,90 & $4646^{ \pm 1,49}$ \\
\hline 19 & 10Яле & 30 & бозмиті щебенюваті & $\mathrm{Hp}$ & $3,0-24,0$ & 1,37 & 2,36 & 40,40 \\
\hline & & & Середньовікові ліси, в & ік 40-60 рог & & & & \\
\hline 2 & $8 C=2 g_{-1}$ & 14 & 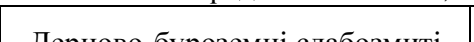 & $\mathrm{H}$ & $0-3,0$ & 2,26 & 4,58 & $45,34^{ \pm 0,38}$ \\
\hline 3 & 8Сз2Яле & 44 & Дерново-оуроземн1 слаоозмит1 & $\mathrm{Hp}$ & $3,0-38,0$ & 1,16 & 2,00 & \\
\hline 4 & 10 gпе & 50 & Бурі лісові неглибокі слабозмиті & $\mathrm{H}$ & $0-5,5$ & 3,32 & 5,73 & $5135^{ \pm 1,56}$ \\
\hline 4 & І0Яле & 50 & щебенюваті & $\mathrm{Hp}$ & $5,5-32,00$ & 1,25 & 2,15 & 51,35 \\
\hline & & & Бурі лісові опідзолені середньог- & $\mathrm{H}$ & $0-5,0$ & 2,92 & 5,03 & $35,49^{ \pm 1,01}$ \\
\hline 8 & 10Яле & 43 & либокі щебенюваті & $\mathrm{Hp}$ & $5,0-28,0$ & 1,06 & 1,83 & \\
\hline 14 & $10 g_{п е}$ & 17 & Буnі пісорі пиибогі & $\mathrm{H}$ & $0-5,0$ & 3,14 & 5,41 & $52,17^{ \pm 0,24}$ \\
\hline 14 & 10ЯЛе & 47 & Бур1 Л1сов1 ГлИоок1 & $\mathrm{Hp}$ & $5,0-26,5$ & 1,29 & 2,22 & $53,1 /=$ \\
\hline & & & Пристигаючі ліси, він & к 60-80 рокі & & & & \\
\hline & & & Бурі лісові середньоглибокі сла- & $\mathrm{H}$ & $0-9$ & 3,20 & 5,51 & 1 \\
\hline 1 & 10Бкл+Яле & 65 & бозмиті щебенюваті & $\mathrm{Hp}$ & $9-31,0$ & 1,34 & 2,31 & $56,48^{ \pm 0,01}$ \\
\hline 2 & 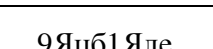 & 75 & Буnі пісові неглибокі шебенюваті & $\mathrm{H}$ & $0-7$ & 3,22 & 5,55 & $5052^{ \pm 0,99}$ \\
\hline 2 & 9ЯцоІЯле & 15 & Бур1 лісов1 неглиоок1 щеоенюват1 & $\mathrm{Hp}$ & $7-37,0$ & 1,33 & 2,29 & $50,52^{-3}$ \\
\hline 5 & & & Бурі лісові неглибокі слабозмиті & $\mathrm{H}$ & $0-5,0$ & 2,98 & 5,14 & $53,03^{ \pm 0,91}$ \\
\hline 5 & 10Яле & 67 & щебенюваті & $\mathrm{Hp}$ & $5,0-19,5$ & 1,48 & 2,56 & $53,03^{-\infty}$ \\
\hline 9 & 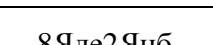 & 75 & Бурі лісові опідзолені середньог- & $\mathrm{H}$ & $0-8,0$ & 3,55 & 6,12 & $1801^{ \pm 1,33}$ \\
\hline 9 & дЯле2Яцо & 15 & либокі щебенюваті & $\mathrm{Hp}$ & $8,0-31,0$ & 1,31 & 2,26 & $48,01^{-3,2}$ \\
\hline 10 & $10 g_{4}$ & 62 & Бурі лісові опідзолені середньог- & $\mathrm{H}$ & $0-6$ & 3,04 & 5,24 & $16,61 \pm 3,82$ \\
\hline 10 & 10ЯцО & 62 & либокі щебенюваті & $\mathrm{Hp}$ & $6-27,0$ & 1,39 & 2,39 & $46,61^{-3,02}$ \\
\hline 12 & 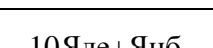 & 75 & Периово бурогемиі & $\mathrm{H}$ & $0-5,5$ & 2,90 & 5,00 & $53,45^{ \pm 1,66}$ \\
\hline 12 & 10Яле+ЯцО & 75 & Дерново-оуроземн1 & $\mathrm{Hp}$ & $5,5-32,0$ & 1,23 & 2,12 & \\
\hline 18 & $6 g_{1}$ & 55 & Бурі лісові середньоглибокі & $\mathrm{H}$ & $0-5,5$ & 3,47 & 5,98 & $43,73^{ \pm 0,70}$ \\
\hline 18 & бЯцОДЯле2ЬкЛ & 55 & слабозмиті щебенюваті & $\mathrm{Hp}$ & $5,5-32,00$ & 1,39 & 2,39 & \\
\hline & & & Бурі лісові середньоглибокі & $\mathrm{H}$ & $0-4,0$ & 2,33 & 4,02 & $36.61^{ \pm 0,}$ \\
\hline 21 & 5Яцб5Яле & 50 & слабозмиті щебенюваті & $\mathrm{Hp}$ & $4,0-36,0$ & 1,08 & 1,86 & $36,61^{ \pm 0,}$ \\
\hline 22 & & 58 & Бурі лісові середньоглибокі & $\mathrm{H}$ & $0-3,0$ & 3,03 & 5,22 & $1310^{ \pm 0,62}$ \\
\hline 22 & 10Яле & 58 & слабозмиті щебенюваті & $\mathrm{Hp}$ & $3,0-34,5$ & 1,29 & 2,23 & 43,19 \\
\hline & & & Стиглі і перестійні ліси, в & ік понад 80 & ооків & & & \\
\hline 7 & 8g & 00 & Бурі лісові середньоглибокі & $\mathrm{H}$ & $0-4,0$ & 3,63 & 6,21 & $75^{ \pm 0,53}$ \\
\hline 7 & 8ЯцО2Яле+Сз & 90 & щебенюваті & $\mathrm{Hp}$ & $4,0-22,5$ & 1,62 & 2,80 & $49,75^{-200}$ \\
\hline & & & & $\mathrm{H}$ & $0-4,0$ & 3,66 & 6,30 & 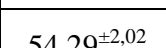 \\
\hline 17 & 10Яцб & 87 & Бурі лісові глибокі & $\mathrm{Hp}$ & $4,0-30,0$ & 1,62 & 2,79 & 54,29 \\
\hline 20 & 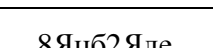 & 82 & Бурі лісові середньоглибокі & $\mathrm{H}$ & $0-5,0$ & 3,35 & 5,78 & $5110^{ \pm 0,67}$ \\
\hline 20 & вЯцо2яле & 82 & слабозмиті щебенюваті & $\mathrm{Hp}$ & $5,0-37,0$ & 1,41 & 2,42 & \\
\hline & & & Зруб, грудень & 2016 & & & & \\
\hline 11 & & : & & $\mathrm{Hp}$ & $0-6,0$ & 1,94 & 3,34 & $3200^{ \pm 0,17}$ \\
\hline 11 & - & - & Бур1 лісов1 глибок1 & $\mathrm{HP}$ & $6,0-39,0$ & 0,69 & 1,18 & $32,00^{-2,17}$ \\
\hline
\end{tabular}

Можна вважати, що внаслідок суцільної рубки відбулася втрата в середньому 20-27 т.га ${ }^{-1}$ органічного Карбону. Встановлено, що сумарний запас органічного Карбону у лісовій підстилці, грубих деревних залишках і грунті на досліджуваній території змінюється від 34,47 т·га до 63,77 т.га $^{-1}$ (рис. 2).

Найбільші запаси органічного Карбону зосереджені у грунті - 79,3-90,9\% на дослідних ділянках, вкритих лісом. Частка запасів $C_{\text {орг. }}$ які припадають на лісову підстилку, становить 7,9-16,1\%, а в грубих деревних залишках міститься лише $0,3 \%-4,8$ \% від загального запасу органічного Карбону. На зрубі частка органічного
Карбону у грубих деревних залишках істотно збільшується за рахунок порубних решток і становить 7,2 \%.

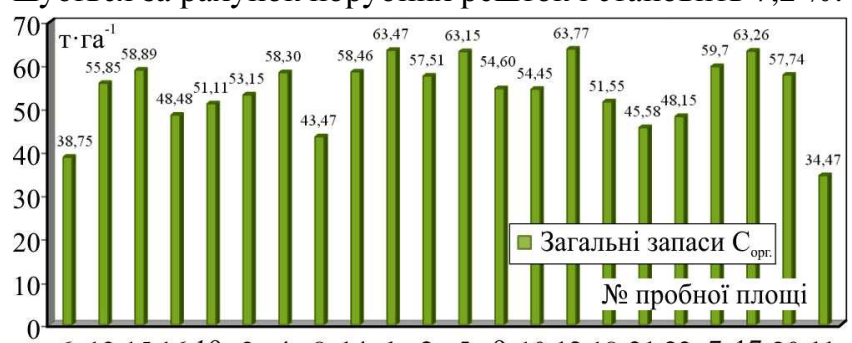

$613151619 \quad 3 \quad 4 \quad 814 \quad 1225591012182122 \quad 7172011$ Рис. 2. Сумарний запас органічного Карбону у досліджуваних екосистемах 
Порівняння результатів наших досліджень і досліджень, проведених раніше на цій території, попри незначні розбіжності, засвідчує, що отримані дані - у межах просторової варіабельності та $є$ репрезентативними для досліджуваної частини Стрийсько-Сянської Верховини. Проте, варто звернути увагу, що для території Верехньовисоцького лісництва зафіксовано досить низькі

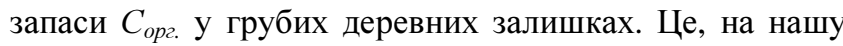
думку, може бути пов'язано з тим, що грубі деревні залишки використовує місцеве населення як паливо, оскільки нема обмеження природоохоронного режиму, як, наприклад у Яблунському лісництві, яке належить до регіонального ландшафтного парку "Надсянський". Збільшення запасів грубих деревних залишків у заповідних лісових екосистемах також зафіксували і польські вчені (Banaś et al., 2014).

Висновки. На території Верхньовисоцького лісництва ДП "Боринське ЛГ", що розташоване в південно-західній частині Стрийсько-Сянської Верховини сумарні запаси органічного Карбону в мортмасі лісових екосистем та 0-25 см шарі грунту становлять 38,75-63,77 т·га 1. На дослідній ділянці після проведення суцільної рубки у грудні 2016 р. зафіксовано найменші запаси органічного Карбону - 34,47 т·га ${ }^{-1}$.

Запаси органічного Карбону у підстилці досліджуваних екосистем становлять $3,94^{ \pm 0,24}-9,07^{ \pm 172} \mathrm{~T}^{\circ} \mathrm{ra}^{-1}$. У лісовій підстилці зосередженого 7,9-16,1 \% від загально-

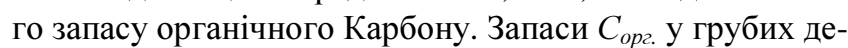
ревних залишках коливаються від 0,16 т га ${ }^{-1}$ до 2,68 т·га ${ }^{1}\left(0,3 \%\right.$ до 7,2 \% від сумарного запасу $\left.C_{\text {ор. }}\right)$. Запаси органічного Карбону у шарі грунту $0-0,25$ м становлять $32,00^{ \pm 0,17}-56,48^{ \pm 0,31} \mathrm{~T} \cdot \mathrm{ra}^{-1}$. Саме у грунті зосереджено найбільші запаси органічного Карбону серед усіх досліджуваних блоків - 79,27-92,83\%.

Суцільні рубки можуть істотно зменшувати запаси органічного Карбону в мортмасі. Так, на ділянці планової суцільної рубки ялинового лісу віком 50-70 років на площі 0,5 га повністю знищено лісову підстилку, верхній гумусовий і частково перехідний горизонти грунту. Порівнюючи цю ділянку із пробними площами, на яких є схожий рослинний покрив та тип грунту, вста-

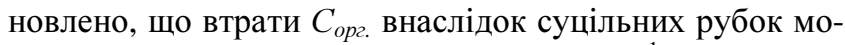
жуть становити на цій території 20-27 т·га ${ }^{-1}$.

Отримані дані актуальних запасів органічного Карбону у мортмасі і грунті лісових екосистем $є$ репрезентативними для досліджуваної території і можуть бути використані для прогнозних оцінок їх змін внаслідок лісокористування на території Стрийсько-Сянської Верховини.

\section{References}

Alekseyev, V. A., \& Berdsi, R. A. (Ed.). (1994). Carbon in ecosystems of forests and peatlands of Russia. Krasnoyarsk: VC SO RAN. [In Russian].

Banaś, Jan \& Bujoczek, Leszek \& Zięba, Stanisław \& Drozd, Marek. (2014). The effects of different types of management, functions, and characteristics of stands in Polish forests on the amount of coarse woody debris. European Journal of Forest Research, 133, 19951107. https://doi.org/10.1007/s10342-014-0825-3.

Bilous, A. (2014). Method of forest dead biomass research. Bioresursy ta pryrodokorystuvannia. Silviculture, 6(3-4), 134-145.

Chestnykh, O. V., Lyzhin, V. A., \& Koksharova, A. V. (2007). The Carbon reserves in litters of forests of Russia. Forestry, 6, 114-121. [In Russian].

Forestry. (2019). State Enterprise Borin Forestry. Vernovysotsky forestry. Retrieved from: https://www.borlis.com.ua/verxnovisockelisnictvo.html

Golubets, A. M. (Ed.) (2007). Conceptual principles of sustainable development of the mountain region. Lviv: Polly. [In Ukrainian].

Grant, M. Domke, Charles, H. Perry, Brian, F. Walters, et al. (2016). Estimating litter carbon stocks on forest land in the United States. Science of the Total Environment, 557-558, 469-478. https://doi.org/10.1016/j.scitotenv.2016.03.090

Lakyda, P. I. (2002). Phytomass of the forests of Ukraine. Ternopil': Zbruch. [In Ukrainian].

Matsala, M. S., \& Bilous, A. M. (2017). Ukrayiny Assessment Carbon in Coarse Woody Debris of Oak Forests in Ukraine. Scientific Bulletin of UNFU, 27(6), 16-19. https://doi.org/10.15421/40270602

Pasternak, V. P. (2011). Bioproductivity of North-Eastern Ukrainian forests in the context of climate change. Diss. Kyiv: National University of Life and Environmental Sciences.

Pyzhyk, I. S., \& Shpakivs'ka, I. M. (2018). Organic carbon reserves in wood debris of forest ecosystems of regional landscape paradise "Nadsyansky" (Ukrainian Carpathians). Biology and valeology: a collection of scientific works, 20, 35-42. Kharkiv: KhNPU. https://doi.org/10.5281/zenodo.2543583

Rozhak, V. P. (2014). Pools and fluxes of carbon within forest ecosystems of Stryi-San Highland (Ukrainian Carpathians). Biology and valeology: a collection of scientific works, 16, 85-95. Kharkiv: KhNPU.

Shpakivska, I. M., \& Maryskevych, O. G. (2009). Estimation the reserves of organic carbon in the forest ecosystems of Eastern Beskydy. Forestry and forest melioration, 115, 176-180.

Skorodumov, A. S. (1939). Opredelenye tolshchyny lesnoy podstylky. Lesnoe khozyaystvo: mezhvuz. sb. nauchn. tr., 12, 41-47. [In Russian].

Tsunyak, A. M., Chaskovs'kyy, O. H., \& Korol', M. M. (2013). Landcover distribution of Stryj-Sjan sublimity on the basis of Landsat satellite images. Scientific Bulletin of UNFU, 23(14), 2731. [In Ukrainian].

Vazhenyna, Y. H. (Ed.). (1974). Methods for the determination of trace elements in soils, plants and waters. Moscow: Kolos. [In Russian].

Volodymyrenko, V. M., Kotlyarevs'ka, U. M., Suray, V. A., \& Klochko, V. M. (2016). Mortmass of Forest Ecosystems in the Modern Eco-Resource Dimension. Scientific Bulletin of UNFU, 26(5), 188-195. https://doi.org/10.15421/40260529

I. S. Pyzhyk, I. M. Shpakivska

Institute of Ecology of the Carpathians, NAS Ukraine, Lviv, Ukraine

\section{ACTUAL STOCKS OF THE ORGANIC CARBON IN MORTMAS AND SOILS OF FORESTRY ECOSYSTEMS OF THE STRYI-SIANSKAYA VERKHOVYNA IN THE TERRITORY OF THE VERNOVYSOTSKE FORESTRY (BORIN FORESTRY ENTERPRISE)}

Forest ecosystems are one of the largest regulators of the carbon cycle on the planet. They are able to absorb and accumulate a large amount of carbon in their components. The study was carried out in the territory of Stryi-Sianska Verkhovyna in the Verkhnivysotsky Forestry (Lviv Region of Turkivsky District). Organic carbon stocks were evaluated in three large pools of forest litter, coarse wood residues and soil. Twenty two sample plots were selected on the territory of the Verkhnivysotsky Forestry. For each plot, samples of forest litter $(n=3)$ and soil $(n=3)$ were selected, and the coarse wood debris stock $(C W D)$ was calculated as 
well. Soil samples were selected from $\mathrm{H}$ and Hp horizons. The stock of dead wood was calculated on the area of $9 \mathrm{~m}^{2}$, which was located on each sample plot. The content of organic matter in forest litter and soil was determined by the method of dry combustion and Nikitina method. To determine the organic carbon stock we used correction coefficients (for forest flooring -0.52 and 0.50 for CWD) and average value dead wood density of $345 \mathrm{kh} \mathrm{m}^{3}$ and soil bulk density. Forest litter reserves in the studied ecosystems are $8.1718 .59 \mathrm{t} \cdot \mathrm{ha}^{-1}$. Stocks of coarse woody debris range from 0.32 to $5.73 \mathrm{t} \cdot \mathrm{ha}^{-1}$. Organic carbon stock is $34.47-63.77 \mathrm{t} \cdot \mathrm{ha}^{-1}$. We have investigated that organic carbon stock in soil ranges from 32.00 to $56.48 \mathrm{t} \cdot \mathrm{ha}^{-1}$, in forest litter $-3.74-9.07 \mathrm{t} \cdot \mathrm{ha}^{-1}$ and in coarse wood debris $-0.16-2.68 \mathrm{t}^{-h^{-1}}$. In the soil its concentration equals $79.27-92.83 \%$ of the total organic carbon stock, in the forest litter7.95-16.11\% and in the CWD - 0.31-7.17\%. Sample plot number 11 is located on the area where deforestation occurred. During the period of deforestation, forest floor was fully destroyed here and $\mathrm{H}$ soil horizon was damaged or destroyed. In the spring, the landslide that occurred here caused even greater destruction of the $\mathrm{H}$ and $\mathrm{Hp}$ soil horizons. We have estimated that the losses of organic carbon in the area are approximately $20-27 \mathrm{t} \cdot \mathrm{ha}^{-1}$. In general, the data obtained are representative of the area and can be used in further studies of organic carbon stocks in the forest ecosystems of the Stryi-Sianska Verkhovyna.

Keywords: The Ukrainian Carpathians; forest litter; coarse wood debris; organic matter; greenhouse gases. 